\title{
Evaluation of Bio-Organic Preparations on Yield of Sharbati Wheat Varieties under Kymore Plateau and Satpura Hill Zone of Madhya Pradesh
}

\author{
Nirjharnee Nandeha* and M.L. Kewat
}

Department of Agronomy, Jawaharlal Nehru Krishi Vishwavidyalaya, Jabalpur, M.P, India

*Corresponding author

\begin{tabular}{l} 
Key w o r d s \\
$\begin{array}{l}\text { Evaluation, Bio-organic, } \\
\text { Yield, Wheat varieties, } \\
\text { Kymore plateau }\end{array}$ \\
\hline Article Info \\
$\begin{array}{l}\text { Accepted: } \\
\text { 04 May } 2018 \\
\text { Available Online: } \\
\text { 10 June } 2018\end{array}$ \\
\hline
\end{tabular}

A B S T R A C T
A field study was conducted in the Department of Agronomy, JNKVV, Jabalpur during 2015-16 and 2016-17 to judge the effect of bio-organic preparations (viz., BD-500, BD501 and panchgavya) blended with vermicompost on the yield of Sharbati wheat varieties. The results showed that the combined application of all bio-organic preparations i.e. BD500, BD-501 and panchgavya along with vermicompost recorded superior values of yield attributes tillers $/ \mathrm{m}^{2}$ (320.94), grains/ear head (27.65), test weight $(36.90 \mathrm{~g})$ and ear length $(7.77 \mathrm{~cm})$ along with noteworthy hike $(22.28,18.25$ and 6.39 percent $)$ in seed yield of wheat over alone application of BD-500, BD-501 and panchgavya with Vermicompost respectively. The Sharbati wheat varieties JW-3020 out yielded to other varieties under organic production system with superior values of yield attributes (tillers $288.30 \mathrm{~m}^{2}$, grains/ear head 28.71, test weight $35.6 \mathrm{~g}$ and ear length $7.40 \mathrm{~cm}$. The cultivation of wheat variety JW-3020 and combined application of all bio-organic preparations (VC+BD$500+\mathrm{BD}-501+$ Panchagavya) along with vermicompost gave higher yield as compared to other combinations of wheat varieties and application of other bio-organic preparations.

\section{Introduction}

Wheat (Triticum aestivum L.) is one of the most important staple food crops of the world. Wheat is grown in about around 219.61 million ha area across 43 countries in the world with the production of 729.1 million tonnes (FAO, 2016). In India, it is cultivated in about 30.97 million hectares area with the production and productivity of nearly 88.94 million tonnes and $2872 \mathrm{~kg} / \mathrm{ha}$ respectively. Madhya Pradesh contributes 17.95 and 15.94 per cent to the total area and production of wheat in the country but the productivity is still low $(2550 \mathrm{~kg} / \mathrm{ha})$ compared to Haryana
$4579 \mathrm{~kg} / \mathrm{ha}$ and Punjab $4495 \mathrm{~kg} / \mathrm{ha}$ (Agriculture Statistics, 2015). Currently, heavy use of chemicals in wheat, has weakened the ecological base and degrading the soil, water resources and quality of the food. At this juncture, a keen awareness has sprung on the adoption of organic farming in which scientific community are working hand in hand to develop a strong workable and compatible package of nutrient management through organic resources viz., biodynamic preparations, vermicompost, panchgavya etc. for various crops. Biodynamic preparations combining biological and dynamic agriculture practices, has recently emerged as an 
advancement in the field of organic agriculture. Biodynamic techniques enhance, rejuvenate, add to and maintain soil quality in terms of biological properties. The biodynamic preparations are believed to work synergistically with $\mathrm{BD}-500$ mainly improving the overall soil fertility and BD- 501 being active in enhancing the plant physiological response to the light radiation (Koepf, 1976). On the other side, Panchgavya is another source of plant nutrients in organic farming which enhances biological activities, soil health and quality. Vermicompost contains significant quantities of nutrients, beneficial microbial population and biologically active metabolites (Jack et al., 2011). Studies of Chandrakala (2008) reported that impact of biodynamic practices and panchgavya alone or in combination for organic nutrient management has been found effective on various crops in different agro-climatic zones. But, very scarce literature is available depicting the combine effect of biodynamic preparations, panchgavya with vermicompost in wheat under organic production system. Most of the farmers are growing traditional varieties of wheat under organic farming which are low yielding. However, there is a wide range of Sharbati wheat varieties of varying duration and productivity which have differential performance under organic management. Hence, it is most important to judge varietal response under varying nutrient management involving alone application of BD-500,501, panchgavya with vermicompost and combined use of all bio-organic preparations with vermicompost for Kymore Plateau and Satpura hill zone of Madhya Pradesh.

\section{Materials and Methods}

The field experiment was conducted during rabi season of 2015-16 and 2016-17 on 'Vertisol' at Adhartal krishi nagar of JNKVV, Jabalpur $\left(23^{0} 90^{\prime}\right.$ North latitude and $79^{0} 58^{\prime}$
East longitude with an altitude of $411.78 \mathrm{~m}$ mean sea level), Madhya Pradesh. This region enjoys sub-humid and tropical climate with hot dry summer and cool dry winters and comes under Kymore Plateau and Satpura hills Agro-climatic zone of Madhya Pradesh and is broadly known as rice-wheat crop zone. The experiment was consisted with seven bioorganic preparations as main plot treatments viz. N1: VC @ 4t/ha+ BD-500 @75 g/ha, N2: VC @ 4t/ha+ BD-501@2.5 g/ha,N3: VC @ 4t/ha+ Panchagavya @3\% at CRI, tillering and jointing, N4: VC @ 4t/ha+ BD-500 @75 g/ha+BD-501@2.5 g/ha,N5: VC @4t/ha+ BD-500@75 g/ha+BD-501@2.5 g/ha+ Panchagavya @3\% at CRI, tillering, and jointing, N6: VC @ 4t/ha (control), N7: Absolute control and four varieties of wheat $\mathrm{V}_{1}$ : C-306 $\mathrm{V}_{2}$ : Sujata $\mathrm{V}_{3}$ : HW-2004 (Amar) and V4: JW-3020 as sub plot treatments and these were laidout in split plot design with thrice replications.

\section{Preparation and application of the biodynamic preparations}

Two biodynamic formulations (BD-500 and BD-501) from the SUPA Biotech (P) Ltd., Nainital, India were tried. BD-500 (horn manure preparation), the "prime starter of biodynamic," is prepared by stuffing the dung of a lactating cow into a horn and buried in the soil during the autumn equinox (September) and taken out during the spring equinox (March). The humified dung from horn is stored in an earthen pot away from sunlight. For preparing the spray solution for one ha, 75 $\mathrm{g}$ of this material was dissolved in 500 litre warm water with continuous stirring for $1 \mathrm{~h}$ (alternately in clock wise and anti-clock wise directions). The liquid mixture was sprinkled as big droplets on soil surface in the evening on day before sowing with the help of broomstick. BD-501 is "cow horn silica" and is made from quartz crystals ground to alum powder consistency, stuffed into a cow horn, 
buried during spring equinox (March), and taken out during autumn equinox (September). BD-501 spray solution was prepared by dissolving $2.5 \mathrm{~g}$ in 500 litre warm water, with continuous stirring for $1 \mathrm{hr}$ to that of BD-500. After an hour, the mixture was sprayed as a fine mist on the plant foliage (i.e. before 9.00 am) with the help of Pneupsack sprayer. Panchagavya was prepared by using the ingredients obtained from the cow viz., cow dung $7 \mathrm{~kg}$, cow urine 3 litre, cow's milk 2 litre, Cow's curd 3 litre, cow's clarified ghee 1 $\mathrm{kg}$. Fresh cow dung and ghee were mixed together and kept in a fresh plastic bucket for two days and this was stirred daily once. On third day, added three liter of cow urine, ten liters of water and fermented it for 12 days and then add two liters of curd, two liters of milk, ferment it for another 15 days. Thereafter, mixture in container was covered with wire mesh and kept under shade for fermentation and stirred thoroughly The contents were stirred for about 20 minutes, both in the morning and evening to facilitate aerobic microbial growth, aeration and to increase the storability period. All the materials were put into a wide mouthed earthen pot and kept open under shade. After 10 days, the Panchagavya stock solution was ready for use. From the stock solution 3 per cent concentration was prepared according to the requirement (To get $3 \%$ concentration, 3 litre of Panchagavya was mixed with 100 litre of water). Out of which, 15 litre solution was mixed in 500 litre of water and was applied using hand sprayer.

\section{Results and Discussion}

Effect of bio-organic preparations on yield attributes and yield

It is obvious from the data presented in Table 1 that all the yield attributing characters, were significantly influenced by the different treatments. Maximum number of effective tillers $\left(320.94 \mathrm{~m}^{-2}\right)$, grains ear ${ }^{-1}(27.65)$, ear length $(7.77 \mathrm{~cm})$ and test weight $(36.90 \mathrm{~g})$ were recorded in the plots receiving combined application of BD-500 + BD-501 + Panchagavya along with vermicompost and proved superior over other treatments except Panchagavya applied with vermicompost and BD-500+BD-501 with vermicompost being the minimum (effective tillers $150.61 \mathrm{~m}^{-2}$, grains ear ${ }^{-1} 18.07$, ear length $5.17 \mathrm{~cm}$ and test weight $29.23 \mathrm{~g}$ ) under absolute control plots.

This may be because of the fact that in Panchagavya presence of naturally occurring beneficial micro-organisms predominately bacteria and certain fungi colonize in the leaves and increase the ammonia uptake and thereby enhancing the total $\mathrm{N}$ supply.

Besides, the presence of growth hormones (IAA and GA) might have favored rapid cell division and cell elongation in crop plants which ultimately stimulated crop growth and development when bio-organic preparations (BD-500+ BD-501 and Panchagavya) were used alone with vermicompost and might have favoured in the formation of superior values of yield attributing traits of Sharbati wheat. However, reverse was true in case of other treatments which had poor values of aforesaid characters.

Grain yield of Sharbati wheat and harvest index were also affected significantly due to different treatments (Table 3). Significantly higher grain yield $\left(2462.17 \mathrm{~kg} \mathrm{ha}^{-1}\right)$, straw yield $\left(3149.87 \mathrm{~kg} \mathrm{ha}^{-1}\right.$ ) and harvest index (43.74 per cent) were recorded under the combined application of BD-500+BD-501+ Panchagavya along with vermicompost followed by Panchagavya with vermicompost and BD-500+BD-501 with vermicompost as these gave a noteworthy hike of $22.28,18.25$ and 6.39 percent on seed yield of wheat over alone application of BD-500, BD-501 and panchgavya with Vermicompost. 
Table.1 Yield attributes of wheat as influenced by different treatments (mean data of 2 years)

\begin{tabular}{|c|c|c|c|c|}
\hline Treatments & $\begin{array}{l}\text { Effective } \\
\text { tillers/m² }\end{array}$ & $\begin{array}{c}\text { Grain/ } \\
\text { Ear head }\end{array}$ & $\begin{array}{c}\text { Test weight } \\
\text { (g) }\end{array}$ & $\begin{array}{c}\text { Ear length } \\
(\mathrm{cm})\end{array}$ \\
\hline \multicolumn{5}{|l|}{ Bio-organic preparations } \\
\hline $\mathrm{N}_{1}: \mathrm{VC}+\mathrm{BD}-\mathbf{5 0 0}$ & 215.95 & 24.80 & 33.76 & 7.35 \\
\hline $\mathrm{N}_{2}: \mathrm{VC}+\mathrm{BD}-\mathbf{5 0 1}$ & 241.41 & 24.84 & 33.92 & 7.43 \\
\hline $\mathrm{N}_{3}: \mathrm{VC}+$ Panchagavya & 303.64 & 26.82 & 35.48 & 7.51 \\
\hline $\mathrm{N}_{4}: \mathrm{VC}+\mathrm{BD}-500+\mathrm{BD}-501$ & 279.56 & 25.73 & 35.44 & 7.48 \\
\hline $\mathrm{N}_{5}: \mathrm{VC}+\mathrm{BD}-500+\mathrm{BD}-501+$ Panchagavya & 320.94 & 27.65 & 36.90 & 7.77 \\
\hline N6: VC (control) & 186.66 & 22.78 & 30.83 & 6.80 \\
\hline N7: Absolute control & 150.61 & 18.07 & 29.23 & 5.17 \\
\hline $\mathrm{SE}(\mathrm{m})$ & 0.94 & 0.39 & 0.14 & 0.08 \\
\hline CD & 2.90 & 1.21 & 0.421 & 0.24 \\
\hline \multicolumn{5}{|l|}{ Varieties } \\
\hline V1: C-306 & 284.18 & 26.12 & 35.35 & 7.14 \\
\hline V2: Sujata & 183.45 & 17.77 & 30.61 & 6.79 \\
\hline V3: HW-2004 & 214.80 & 24.95 & 33.05 & 6.97 \\
\hline V4: JW-3020 & 288.30 & 28.71 & 35.6 & 7.40 \\
\hline $\mathrm{SE}(\mathrm{m})$ & 0.46 & 0.25 & 0.08 & 0.04 \\
\hline CD & 1.33 & 0.72 & 0.24 & 0.12 \\
\hline
\end{tabular}

Table.2 Interaction effect of bio-organic preparations and varieties on grain yield $(\mathrm{kg} / \mathrm{ha})$ of Sharbati wheat varieties

\begin{tabular}{|c|c|c|c|c|c|c|c|c|c|}
\hline Treatments & \multicolumn{8}{|c|}{ Bio-organic preparations } \\
\hline Varieties & $\mathbf{N}_{\mathbf{1}}$ & $\mathbf{N}_{\mathbf{2}}$ & $\mathbf{N}_{\mathbf{3}}$ & $\mathbf{N}_{\mathbf{4}}$ & $\mathbf{N}_{\mathbf{5}}$ & $\mathbf{N}_{\mathbf{6}}$ & $\mathbf{N}_{\mathbf{7}}$ & $\mathbf{m e a n}$ \\
\hline C-306 & 1870.33 & 1900.33 & 2351.00 & 2075.50 & 2500.00 & 1678.17 & 1420.00 & 1970.76 \\
\hline Sujata & 1309.00 & 1568.00 & 1779.83 & 1722.33 & 1893.67 & 1364.00 & 1181.33 & 1545.45 \\
\hline HW-2004 & 1549.83 & 1555.67 & 1906.83 & 1771.00 & 2015.00 & 1485.00 & 1295.00 & 1654.05 \\
\hline JW-3020 & 2925.00 & 3026.50 & 3181.67 & 2983.17 & 3440.00 & 2507.17 & 1860.00 & 2846.21 \\
\hline SE(m) & & & \multicolumn{3}{c}{72.23} \\
\end{tabular}


Table.3 Grain yield, straw yield and harvest index (\%) as influenced by different bio-organic preparations and Sharbati wheat varieties

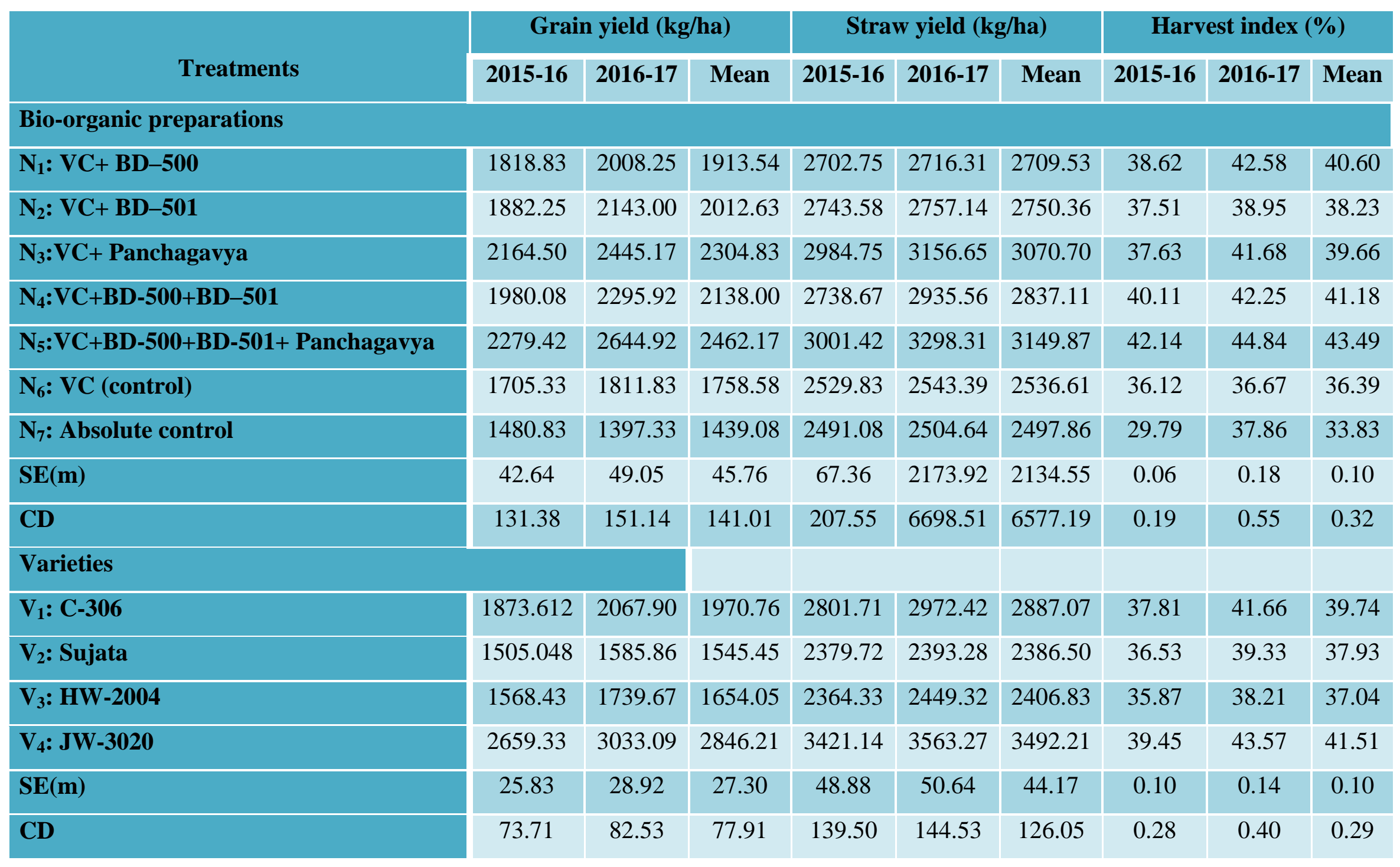


Table.4 Harvest index (\%) of wheat as influenced by different treatment

\begin{tabular}{|c|c|c|c|}
\hline \multirow[b]{2}{*}{ Treatments } & \multicolumn{3}{|c|}{ Harvest index (\%) } \\
\hline & 2015-16 & 2016-17 & mean \\
\hline \multicolumn{4}{|l|}{ Bio-organic preparations } \\
\hline $\mathrm{N}_{1}: \mathrm{VC}+\mathrm{BD}-\mathbf{5 0 0}$ & 39.70 & 41.30 & 40.50 \\
\hline $\mathrm{N}_{2}: \mathrm{VC}+\mathrm{BD}-501$ & 39.99 & 42.91 & 41.45 \\
\hline $\mathrm{N}_{3}: \mathrm{VC}+$ Panchagavya & 42.23 & 44.00 & 43.11 \\
\hline $\mathrm{N}_{4}: \mathrm{VC}+\mathrm{BD}-500+\mathrm{BD}-501$ & 42.12 & 43.84 & 42.98 \\
\hline $\mathrm{N}_{5}: \mathrm{VC}+\mathrm{BD}-500+\mathrm{BD}-501+$ Panchagavya & 43.04 & 44.44 & 43.74 \\
\hline $\mathbf{N}_{6}: \mathrm{VC}$ (control) & 39.85 & 41.24 & 40.54 \\
\hline $\mathbf{N}_{7}$ :Absolute control & 37.13 & 35.64 & 36.39 \\
\hline $\mathrm{SE}(\mathrm{m})$ & 0.79 & 0.73 & 0.74 \\
\hline CD & 2.42 & 2.24 & 2.29 \\
\hline \multicolumn{4}{|l|}{ Varieties } \\
\hline V1:C-306 & 40.01 & 40.89 & 40.45 \\
\hline V2:Sujata & 38.72 & 39.58 & 39.15 \\
\hline V3:HW-2004 & 39.91 & 41.40 & 40.65 \\
\hline V4:JW-3020 & 43.68 & 45.77 & 44.72 \\
\hline $\mathrm{SE}(\mathrm{m})$ & 0.513 & 0.53 & 0.48 \\
\hline CD & 1.46 & 1.50 & 1.38 \\
\hline
\end{tabular}


Superior values of yield attributing traits could be assigned the reason for higher yield of former treatment. Reeve (2011) and Sharma et al., (2011) also endorsed the similar views.

\section{Effect of different Sharbati varieties on yield attributes and yield}

Yield attributing traits of Sharbati wheat varieties were also affected significantly. The effective tillers $\left(288.304 \mathrm{~m}^{-2}\right)$, grains ear $^{-1}$ (28.71), ear length $(28.71 \mathrm{~cm})$ and 1000 -grain weight $(35.59 \mathrm{~g})$ were significantly higher in JW-2030, followed by C-306. But, Sujata had the poor values of effective tillers $(183.45$ $\left.\mathrm{m}^{-2}\right)$, grains ear ${ }^{-1}(17.77)$, ear length $(6.79 \mathrm{~cm})$ and test weight (30.61g). Among the varieties, JW-3020 gave highest grain yield $(2846.21 \mathrm{~kg}$ $\left.\mathrm{ha}^{-1}\right)$ straw yield and (3492.21 kg ha $\left.\mathrm{kg}^{-1}\right)$ followed by C-306 (1970.76 kg ha ${ }^{-1}$ of grain yield and $2887.07 \mathrm{~kg} \mathrm{ha}^{-1}$ ) Application of various bio-organic preparations along with vermicompost might have provided better environment for growth and development of former varieties and finally had better yield attributing values traits, which in turn led to record higher yields of Sharbati wheat varieties. However, varietal differences in yields were mainly due to their genetic characteristics. Bloksma et al., (2011) and Goldstein (2000) also found similar results.

\section{Interactions}

The interaction of bio-organic -preparations and Sharbati wheat varieties caused marked variation on grain yield of wheat (Table 2) wheat varieties JW-3020 and C-306 were out yielded when both were fed with BD500+BD-501+ Panchagavya along with vermicompost followed by the application of Panchagavya. The integrated application of BD-500+BD-501+ Panchagavya with vermicompost enhanced the photosynthetic activities, microbial biomass, nutrient availability and various enzymatic activities within the plants and soil coupled with better genetic traits contributed to higher yield of wheat under former combination of bioorganic preparations and varieties.. However, reverse was true in case of other combinations.

Combined application of application of BD$500+$ BD-501+ Panchagavya along with vermicompost (4 t/ha) in Sharbati wheat varieties JW-3020 and C-306 found more productive than other combinations.

\section{Acknowledgements}

The authors wish to thank the Department of Agronomy, JNKVV, Jabalpur, M.P. for providing the facilities to carry out the work.

\section{References}

Agriculture Statistics. 2015. Agricultural Statistics, Directorate of Economics and Statistics, Department of Agriculture, Cooperation and Farmer Welfare Govt. of India, New Delhi.

Bloksma, J., Northolt, M., Huber, M. 2001. Parameters for apple quality and an outline for a new quality concept. Louis Bolk Institute, Publ. No. FQH 01

Chandrakala M. 2008. Effect of FYM and fermented liquid manure on yield and quality of chilli (Capsicum annuum L.). M.Sc. Thesis, UAS, Dharwad.

FAO. 2016. Crop prospects and food situation. Food and Agricultural Organization of the United Nations, Italy. p 6.

Goldstein WA. and Barber W.2000.A report on previous work done with biodynamic preparations. Biodynamics 129:1-10

Jack, A.L.H., Rangarajan A., Culman S.W., Sooksa-Nguan T. and Thies J.E. 2011. Choice of organic amendments in tomato transplants has lasting effects on 
bacterial rhizosphere communities and crop performance in the field. App Soil Eco, 48(1): 94-101.

Koepf, HH. 1981. The principles and practice of biodynamic agriculture. In Biological Husbandry. A Scientific Approach to Organic Farming (B. Stonehouse, ed.), pp. 237-250. Butterworths; London.
Reeve JR, Carpenter-Boggs L and Sehmsdorf H. 2011. Sustainable agriculture: A case study of a small Lopez island farm. Agricultural Systems 104: 572-579

Sharma, S. N. and Singh R. N. 2011. Seed rate and weed management on yield and nutrient uptake of wheat (Triticum aestivum). Indian J. Agricultural Sciences 81 (12): 1174-9.

\section{How to cite this article:}

Nirjharnee Nandeha and Kewat, M.L. 2018. Evaluation of Bio-Organic Preparations on Yield of Sharbati Wheat Varieties under Kymore Plateau and Satpura Hill Zone of Madhya Pradesh. Int.J.Curr.Microbiol.App.Sci. 7(06): 619-626. doi: https://doi.org/10.20546/ijcmas.2018.706.071 